\title{
Niestabilność prawa w sektorze odnawialnych źródeł energii i jej skutki
}

\author{
Instability of the Law and it's Consequences for \\ the Sector of Renewable Sources of Energy
}

\section{Angelina Sarota}

Ekspert niezależny

ORCID: https://orcid.org/0000-0001-6764-7640

E-mail: angelina.sarota@wp.pl

Abstract

The article presents legislative procedures concerning the renewable energy sources sector. Preparation and adoption of the act on renewable energy sources lasted 5 years, which had a negative impact on investment processes in this area. Legislative regulations have been changed many times, an example of which is the so-called the distance law, that is the Act on Wind Farm Investment. The author points out that the introduction of sudden legislative changes that unexpectedly worsen the legal and economic situation of investors, violating the stability and transparency of the legal system, may be the basis for awarding multi-million-dollar compensations.

Keywords - renewable energy sector, legislation, energy mix, legislative changes, wind farms 


\section{Cele polityki klimatycznej}

Unia Europejska (UE), począwszy od roku 2008, ustanowiła w formie kolejnych tzw. pakietów klimatycznych ambitne cele dotyczące redukcji emisji gazów cieplarnianych i walki z ociepleniem klimatu. Cele te są wielowymiarowe. Dotyczą ograniczania emisji zanieczyszczeń, efektywności energetycznej, zwiększania udziału niskoemisyjnych źródeł energii w konsumpcji energii; obejmują szereg sektorów przemysłowych i gospodarczych oraz utworzenie wspólnego, europejskiego rynku energii. Z uwagi na wieloaspektowość i złożoność tematu, niniejsze opracowanie obejmuje jeden z elementów polityki klimatycznej Unii Europejskiej, jakim jest produkcja energii z odnawialnych źródeł energii, w tym przede wszystkim z wiatru.

Traktat o Unii Europejskiej zawiera 2 kluczowe z punktu widzenia procesu decyzyjnego UE przepisy dotyczące polityki klimatycznej. W art. 192 ust. 2 Traktatu przewiduje się zasadę jednomyślności w odniesieniu do spraw znacząco oddziałujących w danym Państwie Członkowskim na wybór różnych źródeł energii oraz ustalanie zasadniczej struktury miksu energetycznego państwa. Natomiast art. 194 ust. 1 lit. c w związku z art. 194 ust. 2 Traktatu przewiduje zwykła procedurę ustawodawcza (większość kwalifikowana) dla kwestii obejmujących promocję efektywności energetycznej, oszczędności energii oraz rozwoju nowych i odnawialnych form energii [1].

Oznacza to, że w zależności od zakwalifikowania danej decyzji jako mieszącej się w zakresie przedmiotowym jednego z ww. przepisów, w sposób niewymagający lub wymagający jednomyślności, UE może wiążąco wpływać na wybór źródeł energii w danym Państwie Członkowskim. Dla Polski ustalenie wysokiego celu w zakresie udziału odnawialnych źródeł energii w konsumpcii energii, zgodnie z art. 194 (nowe, odnawialne formy energii), oznacza wiążący wpływ decyzji UE na kształt krajowego miksu energetycznego, nawet w sytuacji potencjalnego braku zgody rządu na taką strukturę źródeł energii. Powyższe wydaje się przesądzać o konieczności implementacji przyjętej polityki UE pod rygorem istotnych konsekwencji finansowych nie tylko dla sektora energetycznego w Polsce, ale również dla całej polskiej gospodarki.

Wzrost udziału energii produkowanej w instalacjach odnawialnych źródeł energii stanowi istotny element celów klimatycznych. W roku 2008 Parlament Europejski zatwierdził pakiet zmian legislacyjnych, który ustanowił ogólny cel produkcji energii z odnawialnych źródeł energii (OZE) w bilansie energetycznym Unii w wysokości 20\% 
do roku 2020 [2]. Wielkość tego udziału dla konkretnych państw jest ustalona indywidualnie i dostosowana do konkretnego przypadku, nie może jednak być niższa niż $10 \%$.

W przypadku Polski cel w postaci udziału OZE w krajowej konsumpcji energii do 2020 r. wynosi 15\%. Został on zatwierdzony w przyjętym przez Radę Ministrów 7 grudnia 2010 roku w Krajowym Planie Dziatania w zakresie energii zue źródet odnawialnych [3]. 2 grudnia 2011 roku Rada Ministrów uchwaliła Uzupetnienie do Krajowego Planu Driałania w zakeresie energii že źródeł odnawialnych [4], w którym cel ten został podniesiony do $15,85 \%$.

Z kolei na swoim szczycie w roku 2014 Unia Europejska przyjęła cel w postaci 27\% zużycia energii ze źródeł odnawialnych w całkowitej konsumpcji do roku 2030 [5]. W czerwcu 2018 roku cel ten został podwyższony do 32\%, w ramach propozycji tzw.

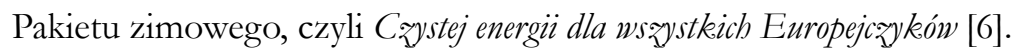

Zgodnie z dyrektywą Parlamentu Europejskiego i Rady o promocji energii ze źródeł odnawialnych i uchylajaca dyrektyny z,2001 i 2003 r. [7], dla osiagnięcia postawionych w zakresie OZE celów niezbędna jest m.in.:

1) Długoterminowa stabilność i przewidywalność dla działalności inwestycyjnej, tworzona przez państwo;

2) Jasne, transparentne i uproszczone procedury wsparcia OZE oraz udzielania zezwoleń;

3) Współpraca i koordynacja między organami szczebla centralnego i samorządowego, dla którego rozwój OZE jest szansą na tworzenie nowych miejsc pracy oraz zapewnienie bezpieczeństwa energetycznego w regionach, wsparcie rozwoju energetyki rozproszonej;

4) Współpraca i realizacja wspólnych programów dotyczących zwiększania konsumpcji energii z OZE między poszczególnymi państwami członkowskimi, w tym zaliczanie do celu $20 \%$ wykorzystania energii wyprodukowanej z odnawialnych źródeł w innym państwie członkowskim;

5) Wprowadzenie świadectw pochodzenia jako quasi papieru wartościowego potwierdzającego pochodzenie energii z OZE. 


\section{Miks energetyczny w Polsce}

Polska jest w grupie najmniej zróżnicowanych krajów wśród krajów Unii Europejskiej, jeśli chodzi o posiadany miks energetyczny, czyli różnorodność źródeł produkcji energii elektrycznej [8]. Udział węgla w produkcji energii elektrycznej w roku 2017 wyniósł $78,4 \%$, OZE - 19\%, w tym lądowe farmy wiatrowe - 13\%, fotowoltaika $1 \%$ i elektrownie wodne $2 \%$, a elektrownie biogazowe i biomasowe - $3 \%$ [8, s. 8]. Należy równocześnie pamiętać, iż dla osiagnięcia w roku 2015 celu 15\% energii z OZE w konsumpcji energii elektrycznej w Polsce, należy brać pod uwagę nie tylko elektroenergetykę ze źródeł odnawialnych, ale również udział zielonej energii w ciepłownictwie i chłodnictwie oraz w transporcie. Udział procentowy tych trzech sektorów celu 15\% wynosił odpowiednio: $54 \%$ dla ciepłownictwa i chłodnictwa, $25 \%$ dla elektroenergetyki i $21 \%$ dla transportu [9, s. 4].

System zielonych certyfikatów przyczynił się do wzrostu mocy zainstalowanej, m.in. w lądowych farmach wiatrowych, w których zanotowano rekordowy wzrost od 3836 MW w roku 2014 do 5500 MW na koniec kwietnia 2016 r. [Ibidem, s. 8-9].

Na przełomie lat 2016 i 2017 inwestycje w OZE załamały się na skutek znacznych zmian legislacyjnych [8, s. 11]. Z punktu widzenia wypełnienia celu OZE w sektorze elektroenergetyki, największy udział - z uwagi na warunki pogodowe i atmosferyczne i dotychczasowy rozwój inwestycyjny - mają lądowe farmy wiatrowe. One również poniosły największe koszty zmian legislacyjnych ostatnich lat. Dlatego analiza przepisów dotyczących OZE w niniejszym opracowaniu dotyczy w głównej mierze lądowych elektrowni wiatrowych, produkujących prąd w ramach prowadzonej działalności gospodarczej.

\section{Systemowe regulacje dotyczące OZE w Polsce}

Wsparcie dla odnawialnych źródeł energii w Polsce datuje się od roku 1999, od kiedy to kolejnymi rozporządzeniami Ministrów Gospodarki w sposób administracyjny kreowano popyt na energię produkowaną w OZE na rynku. Odbywało się to poprzez obowiązek zakupu energii z OZE przez spółki obrotu po określonej, najwyższej taryfowej cenie oraz zapewnienie określonego wolumenu tej energii w obrocie [10;11; 12]. 
Wprowadzono też, zgodnie z prawodawstwem unijnym świadectwa pochodzenia energii ze źródeł odnawialnych, które stanowiły dokument potwierdzający wyprodukowanie określonej ilości energii, w danym przedziale czasu przez producenta OZE. Prawa majątkowe z nich wynikające były - do czasu umorzenia świadectwa - przedmiotem obrotu giełdowego na Towarowej Giełdzie Energii. Przedsiębiorstwa wytwarzania i obrotu energią elektryczną sprzedające energię do odbiorców końcowych na terytorium Polski były zobowiązane do zakupu świadectw pochodzenia i przedstawienia ich do umorzenia Prezesowi Urzędu Regulacji Energetyki lub do uiszczenia opłaty zastępczej.

Ponadto obowiązek zakupu energii ze źródeł odnawialnych został nałożony na sprzedawców z urzędu [13, art. 9a i 9e]. OZE uzyskały wsparcie w zakresie zwalniania z podatków (podatek akcyzowy), zwalniania lub zmniejszania opłat skarbowych, za przyłączenie do sieci i innych opłat, jak również dotacji, nisko oprocentowanych pożyczek i kredytów oraz odrębnych zasad bilansowania handlowego dla farm wiatrowych.

Ponadto ich producenci uzyskali pierwszeństwo w dostępie do sieci przed innymi producentami, poprzez nałożenie na operatora sieci i przedsiębiorstwa dystrybucyjne obowiązku ich przyłączenia w pierwszej kolejności [3, s. 25-28]. Przyjęty przez Radę Ministrów Krajowy Plan działania w zakeresie energii ze źródeł odnawialnych z 2010 r. zapowiadał dalsze ułatwienia do rozwoju OZE w Polsce, które zawarte miały być w dedykowanej temu obszarowi ustawie o energii ze źródeł odnawialnych, której założeniem miało być wdrożenie jednolitego, stabilnego, długofalowego i czytelnego systemu wsparcia dla producentów zielonej energii [Ibidem, s. 30].

Przed uchwaleniem ustawy o OZE, na skutek wszczęcia przez Komisję Europejska przeciw Polsce postępowania przez Europejskim Trybunałem Sprawiedliwości o nałożenie kar finansowych za brak implementacji unijnego prawa, w roku 2013 dokonano częściowej transpozycji dyrektywy poprzez zmianę ustawy Prawo energetyczne (w ramach tzw. małego trójpaku energetycznego) [14, s. 19]. W zakresie OZE zmiana wprowadziła gwarancje pochodzenia energii z OZE, które stanowiły dokument potwierdzajacy odbiorcy końcowemu, że określona ilość wprowadzonej do sieci dystrybucyjnej lub przesyłowej energii została wytworzona w odnawialnym źródle energii; przepisy dotyczace krajowego planu działania w zakresie energii ze źródeł odnawialnych oraz monitorowania rynku energii elektrycznej i innych rynków OZE oraz sprawy dotyczace certyfikacji instalatorów mikroinstalacji i małych instalacji oraz akredytowania organizatorów szkoleń [15, rozdział 2a, 3a i 3b]. 
Przygotowanie i uchwalenie ustawy o odnawialnych źródłach energii trwało 5 lat. Kluczowy rozdział IV tej ustawy, obejmujący mechanizmy i instrumenty wspierające wytwarzanie energii elektrycznej ze źródeł odnawialnych, wszedł w życie dopiero 1 lipca 2016 roku [14, s. 545]. Do tego czasu działalność inwestycyjna w zakresie OZE, w tym dotycząca inwestycji w farmy wiatrowe, odbywała się na podstawie przepisów dotychczasowych, bez prawnej i faktycznej gwarancji stabilnego, długofalowego systemu wsparcia, a wyłącznie w oparciu o ryzyko własne inwestorów i instytucji ich finansujących.

Ustawa o odnawialnych źródłach energii wprowadziła nowy mechanizm wsparcia OZE oparty o system aukcyjny. Ważnym rozróżnieniem jest pozostawienie mechanizmu świadectw pochodzenia dla instalacji, które rozpoczęły wytwarzanie energii po raz pierwszy przed datą wejścia w życie rozdziału IV ustawy [15, art. 42 ust. 1 pkt. 1]. Okres wsparcia $z$ tego instrumentu ustalono na 15 lat od dnia wytworzenia po raz pierwszy energii, potwierdzonego wydanym świadectwem pochodzenia, nie dłużej niż do 31 grudnia 2035 r. [Ibidem, art. 44 ust. 1].

Ustawa o OZE przewiduje również obowiązek umorzenia świadectw pochodzenia (bez możliwości uiszczenia opłaty zastępczej) w sytuacji, gdyby średnioważona cena praw majątkowych wynikających ze świadectw pochodzenia spadła poniżej wartości jednostkowej opłaty zastępczej Ibidem, art. 47 ust. 2]. Wyjątkiem jest wykazanie braku możliwości zakupu tych świadectw w sześciu sesjach w ciagu roku kalendarzowego, z uwagi na brak ofert sprzedaży Ibidem, art. 47 ust. 7]. Mechanizm ten ma przeciwdziałać nadpodaży świadectw pochodzenia i związanego z tym spadku ich ceny na rynku.

Obowiązkowy zakup energii przez sprzedawców zobowiązanych został ograniczony do produkcji z instalacji o łącznej mocy elektrycznej mniejszej niz 500kW (małe instalacje, z wyłączeniem mikroinstalacji), z których energia wytworzona została po raz pierwszy przed dniem wejścia w życie rozdziału IV ustawy (należy zauważyć, że w pierwszej wersji obowiązującej ustawy o OZE obowiązkowy zakup dotyczył wszystkich innych niz mikroinstalacje producentów OZE, którzy wyprodukowali po raz pierwszy energię przed dniem wejścia w życie rozdziału IV).

Cena zakupu tej energii jest regulowana, określona w art. 43 ustawy i stanowi równowartość średniej ceny sprzedaży energii elektrycznej na rynku konkurencyjnym w poprzednim kwartale. W początkowym okresie obowiązywania ustawy instalacje objęte przejściowym systemem wsparcia mogą brać udział w aukcjach, o ile złożą deklaracje przystapienia do aukcji i sa podłączone do sieci dystrybucyjnej lub przesyłowej oraz 
mają umowę przyłączenia [Ibidem, art. 71]. Wytwórcy, którzy pierwszą energię wyprodukująpo dniu zamknięcia sesji aukcji oraz wytwórcy instalacji zmodernizowanych po dniu wejścia w życie rozdziału IV, zgodnie z ustawą powinni uzyskać zaświadczenie o dopuszczeniu do aukcji i podlegają dodatkowo ocenie formalnej.

Z systemów wsparcia określonych w rozdziale IV mogą korzystać wyłącznie wytwórcy, którzy wytworzoną do dnia 31 grudnia 2020 roku energię wprowadzą w całości do sieci oraz sprzedadzą na giełdzie towarowej lub innym rynku regulowanym prowadzonym przez uprawniony podmiot na terytorium Polski. Ustawa określa również koszyki aukcyjne (tzn. źródła energii o określonej mocy, które uczestniczą w danej aukcji) oraz sposób ustalania maksymalnej wartości energii przewidzianej do sprzedania przez państwo w kolejnym roku kalendarzowym i maksymalną cenę referencyjną sprzedaży energii w danej sesji aukcji.

Wyczekiwana od wielu lat ustawa o OZE przyniosła istotne zmiany dla funkcjonowania tego sektora rynku energii elektrycznej. Od jej wejścia w życie, w latach 20152016, była też wielokrotnie nowelizowana, z uwagi na brak precyzji, zmiany dotyczące wsparcia poszczególnych źródeł OZE (mikro i małe instalacje oraz wyodrębnienie biogazu rolniczego) lub luki prawne w niej zawarte (np. w kwestii ustalania tzw. koszyków aukcyjnych). Z uwagi na zmianę systemu wsparcia ze świadectw pochodzenia na system aukcyjny nastapiła luka inwestycyjna, gdyż do czasu ogłoszenia pierwszej nie testowej aukcji wstrzymane są inwestycje w odnawialne źródła energii. W przypadku energetyki wiatrowej na lądzie, rozpoczną one produkcję po zakończeniu procesu inwestycyjnego, ok. dwa lata po rozstrzygnięciu pierwszej aukcji. Aukcja taka do dnia dzisiejszego nie została ogłoszona. Z powyższych powodów przewiduje się lata stagnacji na rynku rozwoju OZE w Polsce [9, s. 10].

\section{Nieoczekiwane zmiany prawne i ich potencjalne skutki}

System zielonych certyfikatów nie spełnił pokładanych w nim nadziei. W stosunku do wyznaczanych limitów produkcyjnych nastapiła nie tylko nadwyżka produkcji zielonej energii, ale również kumulacja certyfikatów za kolejne lata, wpływająca na znaczne obniżenie ich ceny. W roku 2016 można było kupić certyfikaty za ok. 40 zł/MWh, a nawet, w kontraktach dwustronnych za ok. 20 zł/MWh, choć średnia cena na tym rynku utrzymała się w okolicach 100 zł/MWh. Regulowany popyt na zielone certyfikaty w roku 
2015 wyniósł 16,8 TWh, podczas, gdy produkcja wyniosła 22,5 TWh [16]. Zachęty dla producentów technologii współspalania węgla z biomasa przyczyniły się również do dynamicznego rozwoju tej produkcji, z uwagi głównie na jej niskie koszty inwestycyjne, a tym samym do nadpodaży świadectw pochodzenia z tej technologii [17, s. 788].

Duzi państwowi wytwórcy (TAURON, ENERGA, ENEA), którzy zawarli umowy długoterminowe na zakup zielonych certyfikatów z ceną powiązaną z wysokością opłaty zastępczej ustalaną na podstawie ustawy prawo energetyczne, a następnie ustawy o OZE [15, art. 56] w wysokości 300,03 zł za MWh, z powodu spadku ich ceny na rynku, zaczęli ponosić straty. Nowelizacją z 20 lipca 2017 roku Sejm uchwalił ustawę zmieniająca ustawę o OZE w zakresie ustalania opłaty zastępczej wiążąc ją z roczną średnioważoną ceną świadectw pochodzenia i ustalając ją na 125\% tej ceny, jednak nie więcej niż 300,03 zł/MWh [18].

Zmiana ta spowodowała spadek opłaty zastępczej o ok. 2/3, co wpłynęło również na cenę zielonych certyfikatów zakupionych w ramach kontraktów terminowych, w oparciu o wysokość opłaty zastępczej. Poprawiło to sytuację dużych wytwórców energii, głównie państwowych gdyż obowiązujące ich ceny zielonych certyfikatów, na skutek ingerencji ustawodawczej, radykalnie, z dnia na dzień spadły. Natomiast sprzedawcy zielonej energii, równie szybko zostali pozbawieni korzyści, które uzyskali w oparciu o rynkowe kontrakty i na bazie których szacowali swój zwrot z inwestycji w OZE i swoje dotychczasowe zamierzenia inwestycyjne.

Kolejną nieoczekiwaną zmianą ustawodawczą była tzw. ustawa odległościowa, czyli ustawa o inwestycjach w zakresie elektrowni wiatrowych [19]. Przewiduje ona lokalizację elektrowni wiatrowej wyłącznie na podstawie miejscowego planu zagospodarowania przestrzennego (art. 3 ustawy). W sytuacji powszechnego braku takich planów oraz długoletniego procesu ich uchwalania, budowa farm wiatrowych w wielu przypadkach nie jest możliwa. Wcześniej, w sytuacji braku miejscowego planu budowano farmy wiatrowe, podobnie jak i inne inwestycje o charakterze infrastrukturalnym, w oparciu o decyzje o warunkach zabudowy.

Zgodnie $z$ art. 4 omawianej ustawy, farma wiatrowa nie może być zbudowana bliżej niż dziesięciokrotność całkowitej wysokości elektrowni wiatrowej, od gruntu do najwyższego punktu budowli, od budynków mieszkalnych oraz parków narodowych lub krajobrazowych, rezerwatów przyrody oraz obszarów Natura 2000. Natomiast już 
istniejąca farma wiatrowa nie może rozbudować swojej mocy, jeśli nie spełnia tego warunku (art. 12 ustawy).

Jest to najsurowsze prawo dotyczące umiejscowienia wiatraków w Europie. Ponadto, art. 3 pkt. 3 ustawy prawo budowlane rozszerzył definicję budowli nie tylko na część budowlaną elektrowni wiatrowej, ale na wszystkie jej elementy, co kilkukrotnie podwyższyło należny podatek od nieruchomości od tak rozumianej budowli. Dopiero nowelizacja z 7 czerwca 2018 roku przywróciła poprzednie zasady opodatkowania farm wiatrowych, a ustawodawca zdecydował o jej wstecznym, bo od 1 stycznia 2018 roku, wejściu w życie [20].

Prognozowane w związku z planowanym wejściem życie systemu aukcyjnego jedynie zahamowanie rozwoju OZE, w przypadku wiatraków, z powodu dodatkowego wejścia w życie nowych nieoczekiwanych regulacji, okazało się prawdziwą katastrofą. $70 \%$ farm wiatrowych odnotowało w roku 2017 straty, a nawet doszło do upadłości lub wyprzedaży farm wiatrowych [21]. Należy podkreślić, że zmiany dotknęły najszybciej i najdynamiczniej rozwijający się sektor odnawialnych źródeł energii w Polsce, mający też największy potencjał wzrostu z uwagi na warunki naturalne kraju.

Inwestorzy wszczęli już kroki prawne przeciw państwu polskiemu. Podstawą do ich podjęcia może być art. 10 Traktatu Karty Energetycznej [22], który gwarantuje ochronę inwestycji poprzez stwarzanie stałych, sprawiedliwych i przejrzystych warunków dla inwestorów oraz zapewnienie im uczciwego i równego traktowania. Wprowadzanie nagłych zmian legislacyjnych, które nieoczekiwanie pogarszają sytuację prawną i gospodarczą inwestorów, naruszając stabilność i przejrzystość systemu prawa, może być podstawą zasądzenia wielomilionowych odszkodowań.

Taki przypadek wystąpił w Hiszpanii, gdzie państwo przegrało w arbitrażu z brytyjskim inwestorem OZE z powodu radykalnej zmiany polityki energetycznej pogarszającej jego sytuację. Zasądzone odszkodowanie wyniosło $128 \mathrm{mln}$ euro z odsetkami [23].

Analogiczne postanowienia o ochronie inwestycji zawierają także dwustronne umowy o ochronie inwestycji (BIT), których stroną jest Polska. Wprawdzie w sporach między inwestorami z krajów członkowskich Unii Europejskiej, BITy mogą mieć ograniczone zastosowanie, a to z uwagi na orzeczenie Europejskiego Trybunału Sprawiedliwości, który w sprawie Slowakische Republik przeciwko Achmea BV uznał klauzule arbitrażowe w dwustronnych umowach o popieraniu i ochronie inwestycji zawartych 
między państwami członkowskimi UE, za sprzeczne z prawem unijnym [24]. Wyjmują one bowiem wykładnię i stosowanie prawa UE spod kompetencji unijnych sądów.

Nawet jeśli ten wyrok stanie na drodze inwestorom europejskim do uzyskania odszkodowania za brak ochrony przez państwo polskie ich inwestycji w Polsce, nie będzie on miał jednak zastosowania do inwestorów pozaeuropejskich, którzy mogą sięgnąć po tą podstawę dochodzenia swoich roszczeń. Inwestorom europejskim zostanie natomiast wspomniany wcześniej Traktat Karty Energetycznej. Potencjalne procesy związane z ochroną inwestycji wymagają wielomilionowych nakładów finansowych i trwają wiele lat, jednak w przypadku ich wygrania, Polsce grozi zasądzenie na rzecz inwestorów wiatrakowych miliardowych odszkodowań.

\section{Zakończenie}

Analiza stanu oraz zmian prawa w zakresie energetyki odnawialnej w Polsce jest zagadnieniem niezwykle skomplikowanym. Ustalenie właściwego, optymalnego miksu energetycznego w sytuacji dominacji węgla i oparcia gospodarki oraz polityki społecznej na tym zasobie energetycznym wymaga mądrych i odważnych decyzji.

Historia pokazała, że w zakresie rozwiązań dotyczących OZE, rząd nie ustrzegł się błędów, które miały istotne konsekwencje rynkowe. Dlatego też, w szczególny sposób należy wystrzegać się nieprzemyślanych, szybkich zmian legislacyjnych, głęboko ingerujacych i zakłócających system, który wprawdzie pozostaje w okresie permanentnej zmiany, jednak jego cele są bardzo precyzyjnie i konkretnie wyznaczone. Ich niewypełnienie, podobnie jak brak stabilności prawa, może w dłuższej perspektywie oznaczać istotne konsekwencje finansowe, które poniesie całe społeczeństwo.

\section{Bibliografia}

[1] European Union (2012), Consolidated version of the Treaty on the functioning of the European Union, Official Journal of the EU, 26.10.2012, C 326/47

[2] Urząd Regulacji Energetyki (2008), Parlament Europejski zatwierdziit pakiet klimatyczny, https://www.ure.gov.pl/pl/urzad/wspolpraca-miedzynarod/2829,Parlam ent-Europejski-zatwierdzil-pakiet-klimatyczny 
[3] Minister Gospodarki (2010), Krajowy Plan Džiatania w zakeresie energii zue źródeł odnawialnych, http://www.google.pl/url?sa $=\mathrm{t} \& \mathrm{rct}=\mathrm{j} \& \mathrm{q}=\& \mathrm{esrc}=\mathrm{s} \&$ source $=$ web\&c $\mathrm{d}=1 \& \mathrm{cad}=$ rja\&uact $=8 \& \mathrm{ved}=2$ ahUKEwjWzu7L7bPgAhXosIsKHenXDDkQF jAAegQICRAC\&url=http $\% 3 \mathrm{~A} \% 2 \mathrm{~F} \% 2 \mathrm{Fwww.ebb}-$ eu.org\%2Flegis\%2FActionP lanDirective2009_28\%2Fnational_renewable_energy_action_plan_poland_pl.p df\&usg=AOvVaw014Ru0311ajvkB8ZNTxs15

[4] Narodowy Fundusz Ochrony Środowiska i Gospodarki Wodnej (2011), Uzupetnienie do Krajowego Planu Driatania w żakeresie energii ze żródet odnawialnych, http:// nfosigw.gov.pl/download/gfx/nfosigw/pl/nfoopisy/1328/1/4/uzupelnienie_k pd_oze_www.pdf

[5] European Commission (2014), Ramy polityki w zakresie klimatu i energii do roku 2030, https://ec.europa.eu/clima/policies/strategies/2030_pl

[6] PAP (2018), 32 proc. do 2030 r. To nowa dyrektywa unijna w sprawie OZE, Business Insider Polska Business Insider Polska, https://businessinsider.com.pl/wiadomosci/dyrektywa-unijna-w-sprawie-oze-na-2030-r/1c1 rgk5

[7] Parlament Europejski i Rada Unii Europejskiej (2009), Dyrektywa Parlamentu Europejskiego i Rady 2009/28/WE z dnia 23 kwietnia 2009 r. w sprawie promowania stosowania energii ze źródeł odnawialnych zmieniająca i w następstwie uchylająca dyrektywy 2001/77/WE oraz 2003/30/WE, https://eur-lex.europa. eu/legal-content/EN/ALL/?uri=celex\%3A32009L0028

[8] Macuk R., Maćkowiak Pandera j., Rubczyński A (2017), Polska transformacja energetyczna 2017, Forum Energii. Analizy i dialog, http://forum-energii.eu/pl/analizy/polska-transformacja-energetyczna

[9] WYKONANIE CELU OZE 2020. Analiza stanu obecnego i prognoza (2016), (red.) Schnell Ch., SOLIVAN B. Miszkurka Adwokaci i Radcy Prawni sp. p. przy współpracy $z$ WYSOKIENAPIECCIE.PL oraz INSTYTUTEM JAGIELLOŃSKIM

[10] Minister Gospodarki (1999), Rozporządzenie Ministra Gospodarki z dnia 2 lutego 1999 r. w sprawie obowiązku zakupu energii elektrycznej i ciepła ze źródeł niekonwencjonalnych oraz zakresu tego obowiazku, Dz.U. z 1999 r. Nr 13, poz. 119

[11] Minister Gospodarki (2000), Rozporządzenie Ministra Gospodarki z 15 grudnia 2000 r. w sprawie obowiązku zakupu energii elektrycznej ze źródeł niekonwen- 
cjonalnych i odnawialnych oraz wytwarzanej w skojarzeniu z wytwarzaniem ciepła, a także ciepła ze źródeł niekonwencjonalnych i odnawialnych oraz zakresu tego obowiązku, Dz.U. z 2000 r. Nr 122, poz. 1336

[12] Minister Gospodarki (2003), Rozporządzenie Ministra Gospodarki, Pracy i Polityki Społecznej z 30 maja 2003 r. w sprawie szczegółowego zakresu obowiązu zakupu energii elektrycznej i ciepła z odnawialnych źródeł energii oraz energii elektrycznej wytwarzanej w skojarzeniu z wytwarzaniem ciepła, Dz.U. Nr 104, poz. 971

[13] Ustawa z dnia 4 marca 2005 r. o zmianie ustawy Prawo energetyczne oraz ustawy Prawo ochrony środowiska, Dz.U. Nr 62, poz. 552, art. 9a i 9e zmienianej ustawy

[14] Ustawa o odnawialnych źródłach energii - Komentarz (2016), (red. nauk.) Baehr J., Lissoń P., Pokrzywniak J., Szambelańczyk M., Wolters Kluwer, Warszawa

[15] Ustawa z dnia 26 lipca 2013 r. o zmianie ustawy Prawo energetyczne oraz niektórych innych ustaw, Dz.U. poz. 984

[16] Derski B. (2016), Co dalej z zielonymi certyfikatami?, WysokieNapiecie.pl, https://wysokienapiecie.pl/1861-zielone-certyfikaty-cena-nadpodaz-obowiazek-2016-2020/

[17] Janik B. (2014), Determinanty zmienności cen zielonych certyfikatów, „Zeszyty Naukowe Uniwersytetu Szczecińskiego. Finanse, Rynki Finansowe, Ubezpieczenia” nr 67 Narzędzia zarządzania finansami

[18] Ustawa z dnia 20 lipca 2017 r. o zmianie ustawy o odnawialnych źródłach energii, Dz.U. 2017, poz. 1593

[19] Ustawa z dnia 20 maja 2016 r. o inwestycjach w zakresie elektrowni wiatrowych., Dz.U. 2016, poz. 961

[20] Ustawa z dnia 7 czerwca 2018 r. o zmianie ustawy o odnawialnych źródłach energii oraz niektórych innych ustaw, Dz.U. 2018 poz. 1276

[21] Prawie 70 proc. farm wiatrouych notuje straty (2018), Teraz-srodowisko.pl, https:// www.teraz-srodowisko.pl/aktualnosci/prawie-70-proc-farm-wiatrowych-notujestraty-4231.html

[22] Traktat Karty Energetycznej oraz Protokół Karty Energetycznej dotyczący efektywności energetycznej i odnośnych aspektów ochrony środowiska, sporządzone w Lizbonie dnia 17 grudnia 1994 r., Dz.U. 2003, nr 105, poz. 985 
[23] Judkiewicz M. (2017), Hiszpańscy inwestoryy z. braníy energii stonecznej uygrali z rzadem, Teraz-srodowisko.pl, https://www.teraz-srodowisko.pl/aktualnosci/hiszpania-i nwestorzy-oze-wygrali-3343.html

[24] Trybunał Europejski (2018), Sprawa C-284/16 Slowakische Republik vs Achmea BV, http:// curia.europa.eu/juris/liste.jsf?language=pl\&td=ALL\&num=C-284/16 